\title{
As ações policiais diante dos tribunais - Rio de Janeiro em meados do século $\mathrm{XX}^{1}$
}

\author{
Rivail Carvalho Rolim ${ }^{2}$
}

\begin{abstract}
Sumário: Introdução; 1. O cenário social do Brasil em meados do século XX; 2. Ação policial e os autos criminais; Conclusão. Referências.
\end{abstract}

Resumo: Em meados do século XX, a sociedade brasileira vivenciou um intenso processo de urbanização e industrialização, formando com isso grandes áreas metropolitanas nas principais cidades do país. Esse novo cenário social passou a ser alvo de grande preocupação, pois considerava-se que os contingentes populacionais residentes das áreas periféricas das cidades não possuíam nível cultural necessário para viver de acordo com os padrões sociais da modernidade, e em consequência acabavam tendo comportamentos antissociais e antijurídicos. $\mathrm{O}$ aparato policial passou a ser visto como de fundamental importância para reprimir esse tipo de conduta e manter a ordem pública. Segundo preceitos constitucionais, essas ações policiais, com o uso da força física, deveriam ser realizadas dentro dos padrões da legalidade. Diante desse cenário, o poder judiciário se viu diante do desafio de resolver os episódios nos quais policiais usavam a força física no desempenho de suas atividades. Para acompanhar essa questão, analisamos como foram julgados pela justiça criminal os policiais acusados de cometer abusos e arbitrariedades no exercício de sua função.

Palavras-chave: ideias jurídico-penais; justiça criminal; ação policial; direitos civis.
Abstract: Brazilian society of the mid-20th Century experienced a profound urbanization and industrialization process and the establishment of huge metropolitan areas around the main cities of Brazil. The new social environment became the object of grave concern since the population now living at the cities' periphery was thought to be incapable of having the necessary cultural level to live according to modern social standards. Antisocial and anti-juridical behavior would be the consequence. Since people living at the periphery were thought to be potential criminals, the whole police apparatus was seen to be of paramount importance to enforce such behavior and maintain public order. Police action and physical enforcement should be actually done within legal standards according to the Constitution. The courts were thus made to solve problems in which the police used physical force when performing its duty. Research comprises analysis on the manner the courts judged police officers who were accused of committing abuses and arbitrary crimes while exercising their duties.

Keywords: juridical and penal concepts; criminal justice; police activities; civil rights.

\footnotetext{
1 Versão resumida deste trabalho foi apresentada no V Congresso Europeu de Latinoamericanistas, Bruxelas, de 11 a 14 de abril de 2007.

2 Professor do Departamento de História da Universidade Estadual de Maringá-PR; Doutor em História pela Universidade Federal Fluminense-RJ.
} 


\section{Introdução}

A conjuntura histórica que vai do final do Estado Novo até meados da década de 1960 é marcada pela ênfase na construção de um Estado moderno no Brasil. Na realidade, a sociedade brasileira passou a vivenciar um intenso processo de industrialização, de mudanças de valores culturais e grande efervescência de projetos políticos. Diante dessas condições criou-se um clima de otimismo, no qual se acreditava que o país rapidamente integraria o grupo dos países desenvolvidos.

Juntamente com essas profundas mudanças, houve também um rápido processo de urbanização, formando grandes contingentes populacionais nas áreas metropolitanas e nas inúmeras cidades médias espalhadas pelo país. Esses segmentos sociais passaram a ser motivo de grandes preocupações, eram vistos como marginais que não conseguiriam se incorporar à nova dinâmica social.

Caracterizada pela redefinição dos termos da vivência social devido ao rápido processo de urbanização e modernização da sociedade brasileira, a justiça criminal procurou administrar o desenrolar das relações entre os indivíduos e os grupos sociais mediante normas jurídicas recémimplantadas. Foram promulgados o Código Penal (Decreto Lei oㅜ 2.848 de 7 de dezembro de 1940), o Código de Processo Penal (Decreto Lei no 3.688 de 3 de outubro de 1942) e a Lei de Contravenções Penais (Decreto Lei no 3.689 de 3 de outubro de 1942).

Nosso objetivo é analisar o funcionamento da justiça criminal, especialmente nos casos em que policiais foram acusados de cometer abusos e arbitrariedades no exercício de sua função. Pretendemos avançar na compreensão do papel do poder judiciário em julgar se o Estado aparato policial - exercia o monopólio da violência dentro dos padrões da legalidade.

A problemática desta pesquisa foi sendo construída a partir do momento em que alguns pesquisadores assinalaram que processos de democratização não significam necessariamente que os direitos fundamentais estejam assegurados (ADORNO, 1994, 1995; PANDOLFI, 1999; PINHEIRO, 1991). Não só isso, a experiência republicana brasileira tem sido marcada por uma ordem racional-legal com grandes dificuldades para adotar princípios universalistas em termos de direitos civis e individuais e assegurar o controle da violência legal. 
No encaminhamento das nossas reflexões, partimos do pressuposto teórico de que as práticas penais não podem ser explicadas somente a partir da lógica jurídica, conforme muito demonstraram Georg Rusche e Otto Kirchheimer (2004) em um clássico trabalho produzido na década de 1930. Para esses pensadores da Escola de Frankfurt, as formas de punição têm uma estreita relação com a dinâmica social, sendo possível, por conseguinte, entendê-las somente se observados os sistemas de punição concretos e as práticas penais específicas. Eles afirmaram enfaticamente, por exemplo, que a "afinidade, mais ou menos transparente, que se supõe existir entre delito e pena impede qualquer indagação sobre o significado independente da história dos sistemas penais" (RUSCHE; KIRCHHEIMER, 2004, p. 19).

Em conformidade com os apontamentos de Rusche e Kirchheimer (2004), para uma análise das práticas penais, faz-se necessária uma abordagem histórica, sob pena de não se entender a relação existente entre os sistemas de punição e as realidades históricas determinadas. Mario Bretone (2000, p. 71), ao comentar o pensamento de Von Savigny, expoente da Escola Histórica de Direito na Alemanha, pontua que a história permite identificar e entender o que é próprio de cada época e de cada forma jurídica. Pierre Bourdieu (1989) assinala não ser possível entender o direito como um sistema fechado e autônomo, como se estivesse completamente distante dos constrangimentos e das pressões sociais e tivesse nele mesmo o seu próprio fundamento.

O recorte desse tempo histórico para nossas reflexões deve-se justamente à singularidade vivida pela sociedade brasileira na conjuntura dos marcos desta pesquisa. Havia a crença na construção de um Estado moderno e na implantação de um projeto de nação que mudaria as estruturas sociais, econômicas e políticas. Jorge Ferreira (2001) chega a ressaltar que na década de 1950 homens e mulheres acreditavam que seriam encontrados os meios necessários para se alcançar o real desenvolvimento do país e o efetivo bem-estar da sociedade. Portanto, estávamos diante de um cenário social propício para a efetivação de princípios e postulados de uma justiça moderna.

Para o encaminhamento das reflexões, na primeira parte deste artigo analisamos a conjuntura histórica vivida pelo país para visualizarmos o cenário social no qual o poder judiciário atuou. Como nosso intuito de 
apreender o funcionamento da justiça criminal, analisamos na segunda parte alguns autos criminais em que policiais foram denunciados por cometerem atos ilegais no exercício da função. Selecionamos processos criminais da cidade do Rio de Janeiro, então capital da República.

\section{0 cenário social do Brasil em meados do século $\mathrm{XX}$}

Com o fim do Estado Novo e da Segunda Guerra Mundial acentuase o processo de modernização da sociedade brasileira. Consequentemente avança a implantação de um sistema industrial, com um mercado interno dotado de dinamismo próprio e com certa autonomia. Nesse contexto, o país passou a produzir: petróleo e seus derivados; têxteis; calçados; bebidas; fármacos; produtos de beleza; até as maravilhas eletrodomésticas. Como resultado, nesses quinze anos, a produção industrial quase sextuplicou. No sistema da comercialização, as vendinhas e os armazéns foram sendo suplantados pelos supermercados e shopping centers.

Essas condições econômicas favoráveis propiciaram a criação de um clima de otimismo no qual se considerava que o país vivenciava um momento de "possibilidades mágicas", podendo lançar-se em um voo rumo ao seleto mundo das nações desenvolvidas. Segmentos sociais residentes nas áreas urbanas acreditavam que o Brasil em pouco tempo se integraria ao primeiro mundo. Para Lucília de Almeida Neves (2001, p. 202), esse ideário tinha como principal ingrediente a "crença na resolução dos problemas sociais do país, na superação do subdesenvolvimento que assolava a economia brasileira e na construção de uma nação soberana".

Meios de comunicação de massa, como o rádio, principal veículo de preferência popular, a televisão, que dava seus primeiros sinais de vida, a imprensa escrita e o cinema tratavam de difundir essa crença unilateral no progresso e atualizar o país em relação à modernidade dos centros industrializados. João Manuel Cardoso de Mello e Fernando Novais (2006, p. 560) assim se reportam a esse período:

Na década de 50, alguns imaginavam até que estaríamos assistindo ao nascimento de uma nova civilização nos trópicos, que combinava a incorporação das conquistas materiais do capitalismo com a persistência dos traços de caráter que nos singularizavam como povo: a cordialidade, a criatividade, a tolerância. 
Esse imaginário se materializava nas cidades espalhadas por todo o território nacional por meio da implantação das redes de água e esgoto, construção de grandes avenidas, edificação de uma arquitetura moderna, ruas pavimentadas e iluminadas. Não apenas isso, mas também por terem sido abertas inúmeras rodovias interligando as principais cidades do país para dar vazão ao tráfego de automóveis made in Brazil, um dos signos da modernidade (ROLIM, 2005).

Ângela de Castro Gomes (2006, p. 498) assevera que "a década de 50 , como o fizera a de 20 recoloca de maneira particularmente enfática para políticos, intelectuais e para a sociedade em geral, as questões da construção de um Estado moderno no Brasil". Referindo-se também à década de 1950, Alzira Alves de Abreu (1996, p. 14) preconiza que:

Foi uma década de concretização de muitas idéias e projetos elaborados durante ou após a guerra, de realizações nos campos político, econômico, social e cultural. Período de funcionamento do regime democrático, o que evidentemente permitiu a livre expressão de idéias e o desabrochar da criatividade em todas as áreas de conhecimento.

No entanto, se estava presente essa euforia e esse otimismo no universo das áreas metropolitanas e nas inúmeras cidades espalhadas pelo território nacional, havia também uma realidade de conflitos intensos mostrando o avesso desse ideário hegemônico largamente difundido entre os segmentos sociais durante os "anos dourados". O padrão de vida de diversos segmentos sociais, residentes nos espaços urbanos no pós-guerra, não condizia com esse ufanismo.

Devido às próprias características do desenvolvimento industrial no Brasil, as classes populares não encontravam oportunidade de trabalho estável e produtivo; oscilavam entre desemprego, atividades ínfimas de produtividade e subemprego. Em um curto espaço de trinta anos (1950-1980) o Brasil tornou-se uma sociedade urbano-industrial; entretanto, tanto a estrutura de seu sistema urbano quanto as ocupações se moveram no sentido de aguçar os desequilíbrios e as desigualdades. Neste sentido, apesar de ter havido um relativo dinamismo do emprego industrial, houve a persistência de acentuados níveis de desigualdade e pobreza no país (FARIA, 1983, p. 154). 
Foi intensificada a migração das pessoas das áreas rurais para as cidades em busca de melhores condições de vida. Morar nos centros urbanos significava a possibilidade de arrumar um emprego melhor, com um bom salário, além de contar com a proteção das leis trabalhistas e poder usufruir os serviços sociais existentes, como hospitais e escolas. João Manuel Cardoso de Mello e Fernando Novais (2006, p. 574) expõem que "a vida na cidade atrai e fixa porque oferece melhores oportunidades e acena um futuro de progresso individual, mas também, porque é considerada uma forma superior de existência. A vida do campo, ao contrário, repele e expulsa".

Em função desse fenômeno migratório, a taxa de crescimento anual no espaço urbano na década de 1950 chegou a 6,31\%, caindo na década de 1960 e seguintes. O índice maior foi justamente nas cidades com 100 a 500 mil habitantes (FARIA, 1983, p. 127-129). Alba Zaluar (2006, p. 269) esclarece que essa aceleração, entre a "década de 50 até a de 70 , fez surgir grandes regiões metropolitanas e muitas cidades médias no interior do país". Nesse âmbito, podemos até afirmar que o fenômeno de urbanização na sociedade brasileira ao longo dessa conjuntura não se restringiu às áreas metropolitanas como comumente se postula. Cardoso de Mello e Novais (2006, p. 585) assim se manifestam ao mesmo período:

Os trinta anos que vão de 1950 a 1980 - anos de transformações assombrosas, que, pela rapidez e profundidade, dificilmente encontram paralelo neste século - não poderiam deixar de aparecer aos seus protagonistas senão sob uma forma: a de uma sociedade em movimento. Movimento de homens e mulheres que se deslocam de uma região a outra do território nacional, de trem, pelas novas estradas de rodagem, de ônibus ou amontoados em caminhões paus-de-arara.

Tratando especificamente do Rio de Janeiro, capital da República, identifica-se um cenário social onde dos 405.999 prédios existentes em 1950, 44.621 eram moradias em favelas e das 94 mil construções entre 1940 e 1949, 24 mil eram barracos (LOBO, 1992). Dois jornalistas da revista Manchete, ao se aventurarem pelos bairros populares da capital do país, relataram que "a trinta metros da Praça Mauá nos sentíamos tão distantes da Cidade Maravilhosa como se nos encontrássemos nas lonjuras do Amazonas" (VENTURA, 1991, p. 21). 
$\mathrm{Na}$ realidade, a trajetória histórica da cidade do Rio de Janeiro ao longo do século XX está indissociavelmente ligada às favelas. Como ressalta Angelina Peralva (2000, p. 45), "elas acompanharam pari passu a evolução da cidade, a expansão de suas fronteiras, a formação sucessiva de novos bairros. São parte importante da identidade carioca". Acrescenta que, favorecido pela topografia local, um tipo particular de segregação tomou forma com as favelas. O espaço urbano foi organizado de duas formas: a planície, local das classes mais favorecidas, e os morros, espaços dos segmentos que foram expulsos das áreas centrais da cidade.

Ainda citando Angelina Peralva, se as favelas foram ignoradas pelos poderes públicos até meados do século, ao longo dos anos 1950 isso começa a se modificar. Ocorreram inúmeros debates acerca dos habitantes das favelas e dos morros próximos ao centro da cidade. Para o representante do Serviço de Recuperação de Favelas e Habitações Anti-Higiênicas da Prefeitura do Distrito Federal, "as favelas cariocas se tornaram mais do que um problema urbanístico, são um perigoso sintoma de subdesenvolvimento econômico de graves conseqüências sociais" (MEUREN, 1959, p. 459).

Diante desse quadro, os governos passaram a desenvolver inúmeras ações para erradicar essas moradias da cidade, removendo as pessoas para conjuntos habitacionais distantes do centro. No Governo Carlos Lacerda, início da década de 1960, essa prática se firmou como política sistemática tal a obsessão do Poder Executivo em "limpar a cidade" dos indesejáveis. O Conjunto Habitacional Cidade de Deus é o exemplo mais significativo. Alba Zaluar (1985, p. 67) aponta que:

Cidade de Deus, cuja ocupação se iniciou em 1965 e se estendeu pelos três anos seguintes, foi primeiramente invadida pelos flagelados das enchentes de 1966 para depois vir a abrigar oficialmente outros flagelados que vieram ocupar as 930 casas de triagem, isto é, de transição pelo conjunto, juntamente com favelados vindos de 63 favelas localizadas nas mais diferentes áreas da cidade.

A realidade é que determinados segmentos sociais desfrutavam as vantagens de um processo de transformação; contudo, outros estavam sendo excluídos. Não só isso, eram vistos como consequências 
indesejáveis, porém inevitáveis. E essa presença bastante visível das classes populares, principalmente nas grandes cidades, gerou certa apreensão. Zuenir Ventura (1991, p. 20), em seu romance, assevera que "a partir de 1953 a percepção da violência urbana começou a se fazer sentir com mais destaque na imprensa". Cresceu o temor de que o país estava vivenciando um período de desagregação e quebra dos valores. Os criminalistas mais renomados alertavam que os índices de criminalidade haviam aumentado.

O fato de determinados segmentos sociais estarem sendo excluídos dos ganhos materiais ou mesmo não se inserindo no movimento de modernização da sociedade fez com que houvesse, por parte do pensamento social brasileiro, um processo de apropriação das teorias sobre a marginalidade social (ROLIM, 2007). No que tange à recepção dessas ideias no país, não podemos perder de vista que "a aceitação de mensagens, modelos sempre operam através de ajustes, combinações ou resistências", conforme esclarece Roger Chartier (1992, p. 234).

As teorias relativas à marginalidade social surgiram nos Estados Unidos a partir da década de 1920 com o intuito de produzir um diagnóstico sobre a integração dos imigrantes no país. De acordo com essas formulações, etnias que haviam migrado para a sociedade americana viviam em crise, porque estavam ligadas à cultura de seu país de origem e da terra de destino (KOWARICK, 1975, p. 25). Para Everett Stonequist, autor do clássico trabalho $O$ homem marginal, traduzido inclusive para a língua portuguesa no final da década de 1940, “o indivíduo seria um recipiente que vive as incompatibilidades de quadros referenciais contraditórios, e, como consequência, torna-se um marginal" (apud KOWARICK, 1975, p. 26).

No Brasil, as teorias referentes à marginalidade social partiram do pressuposto de que as cidades estavam sendo ocupadas - alguns chegavam a dizer invadidas - por migrantes de regiões atrasadas e arcaicas que, ao encontrarem dificuldades para se integrar à nova sociedade, viviam em uma situação marginal. Para Cardoso de Mello e Novais (2006, p. 574), "matutos, caipiras, jecas: certamente era com esses olhos que, em 1950, os 10 milhões de citadinos viam os outros milhões de brasileiros que moravam no campo, nos vilarejos e cidadezinhas de menos de $20 \mathrm{mil}$ habitantes. Olhos, portanto, de gente moderna, 'superior', que enxerga gente atrasada, "inferior'". 
A marginalidade é concebida enquanto um problema de assimilação deficiente em que os padrões modernos deixam de ser incorporados. Como conseqüência, "nem todos os grupos sociais teriam o instrumental necessário para participar das formas de produção e de consumo da civilização urbano-industrial" (KOWARICK, 1975, p. 50). Portanto, tal qual haviam definido Robert Park e Everett Stonequist, o entendimento era de que o Brasil passava pela mesma problemática, qual seja, de que havia o homem marginal, todavia aqui se tratava de pessoas migrantes das áreas rurais.

As classes populares no país eram concebidas como um segmento social marcado pela privação, pela carência, pelo desvio, porque não tinham haurido a mentalidade dos tempos modernos. Essas teorias sociais se manifestaram também no campo jurídico, tendo em vista que se formulou um paradigma explicativo acerca da conduta e do comportamento desses segmentos sociais, que de antemão já eram tidos como marginais. Para Nelson Hungria (1951, p. 11), um destacado criminalista, por exemplo, havia o seguinte pressuposto:

Nas cidades, são 'gente do morro', congestionando improvisados 'barracos' ou 'mocambos', os párias das 'cabeças de porco' e dos porões infectos, aglomerando-se numa promiscuidade de arrepiar, a braços com todas as necessidades, forçadamente habituados à penúria, subnutridos, esfarrapados, sem o mais elementar conforto e higiene, lavrados pela sífilis e pelo álcool, com um insuficiente mínimo de aquisições éticas ou com critérios morais deturpados, entregues à licenciosidade sexual (sem exclusão do próprio incesto) e aos vícios de toda ordem, solidários em todos os maus costumes (formando-se entre certos grupos um verdadeiro sprit de corps para o crime), sem qualquer espécie de vida recreativa, uns sem profissão definida e outros mal ganhando para o próprio sustento e o da família provinda da mancebia.

Se a concepção era de que parcelas significativas da população viviam na marginalidade por possuírem comportamentos inadequados para uma sociedade que procurava se inserir na dinâmica da modernidade, para o pensamento jurídico-penal elas eram responsáveis por atos anti-sociais e antijurídicos. Romão Cortes de Lacerda (1959, p. 520), Desembargador do Tribunal de Justiça do Distrito Federal, destacou que "algumas vozes autorizadas se fazem ouvir acerca do alarmante recrudescimento da 
criminalidade entre nós, notadamente na modalidade violenta". César Veiga (1952, p. 547) apregoa que não só havia aumentado a criminalidade, mas ocorria uma "multiplicação em sua variedade, aparecimento de ações criminosas de espécie rara, ou mesmo inéditos até então".

Em função dessa percepção sobre o aumento da criminalidade, com ações raras ou até mesmo inéditas segundo César Veiga, os operadores do campo jurídico argumentaram que era necessário observar não só a materialidade do fato, ou seja, o crime em si, mas os aspectos subjetivos presentes na quebra da norma jurídica. As preocupações estavam voltadas para elucidar/identificar o "caráter do agente", o "temperamento", a "conduta anterior ou subseqüente ao fato", a "personalidade" e a "constante ou estável intimidade psíquica" para se recorrer às noções jurídicas largamente empregadas pelo pensamento jurídico-penal.

Por conseguinte, estamos diante de uma conjuntura histórica caracterizada por mudanças sociais e econômicas significativas e pela pregnância na cultura jurídico-penal de que as classes populares possuíam um comportamento caracterizado pela insuficiência nas aquisições éticas, critérios morais deturpados e estavam entregues aos vícios de toda ordem e solidários nos maus costumes. Aliás, para Nelson Hungria (1947, p. 267), "o código penal é essencialmente destinado aos inferiorizados psíquicos, pois raramente outros incorrem nas suas ações”.

Essas ideias jurídico-penais terão desdobramentos significativos em relação ao funcionamento da justiça criminal, visto que os processoscrime contra os policiais serão julgadas no interior dos tribunais em função dos princípios e postulados produzidos pelo campo jurídico.

\section{Ação policial e os autos criminais}

Como temos a intenção de acompanhar o funcionamento da justiça criminal nos episódios em que policiais foram denunciados por agirem fora da lei, selecionamos alguns autos criminais. Adotamos como metodologia a observação de indícios e pormenores, muitas vezes negligenciáveis, porque entendemos que isso pode ser mais eficaz na revelação das ações policiais na capital da República nos marcos desta pesquisa.

Estamos nos alicerçando nas formulações metodológicas de Carlo Ginzburg (1989), para quem o paradigma indiciário pode nos ajudar a sair 
dos incômodos da contraposição entre 'racionalismo' e 'irracionalismo', uma vez que concebemos de fundamental importância os detalhes, as particularidades para se captar uma realidade mais profunda, de outra forma inatingível. Não só nisso, mas no pressuposto teórico de que cada um dos episódios contidos nos autos criminais revela aspectos significativos sobre a ação policial no Rio de Janeiro e de como foram conduzidos os julgamentos.

Para o encaminhamento das reflexões, nos detemo-nos em cada um dos autos criminais para assinalar como foi construído o modelo de culpa e de inocência dos policiais acusados. Assim nos foi possível entender qual o padrão utilizado pela justiça criminal para lidar com as ações nas quais policiais foram denunciados por agirem fora dos padrões da legalidade. Ademais, foi-nos permitido apontar como os policiais utilizaram várias noções jurídicas no interior dos tribunais para legitimar as ações arbitrárias cometidas no exercício de sua função. Podemos acrescentar que a forma como a justiça criminal encaminhou as denúncias feitas contra os agentes policiais indica como o Estado brasileiro enfrentou a questão da violência ilegal em um dos períodos mais significativos da história republicana brasileira.

O primeiro processo refere-se a um homicídio ocorrido no bairro de Magalhães Bastos no final da década de 1950, cometido por um guarda civil morador do local. A vítima era um operário de 31 anos. O Boletim de Ocorrência foi elaborado a partir das informações prestadas pela

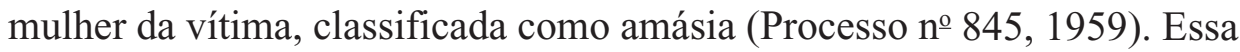
rotulação imputada à esposa coloca o casal próximo da marginalidade, porque pontua que a ordem jurídica não reconhece a união conjugal.

No Boletim de Ocorrência, consta que, quando a vítima estava chegando embriagada em casa, discutiu com o vizinho por causa de uma filha menor. Ao adentrar em seu domicílio, foi abordada pelo guarda civil, morador nas imediações. Reagiu e empurrou o invasor para fora de sua residência, afirmando que ali ninguém entraria. Relata a mulher da vítima que o guarda civil retrucou, dizendo que buscaria em casa o que seu marido queria. Em seguida seu esposo saiu armado de uma faca de mesa. Algum tempo depois, foi avisada pela vizinha que ele estava morto.

Como estava claro quem era o responsável pelo homicídio, os agentes policiais passaram a delinear o perfil das pessoas envolvidas para 
poderem identificar aspectos subjetivos que envolviam a quebra da norma jurídica. Para tanto, intimaram várias pessoas presentes no episódio e também vizinhos que pudessem fornecer maiores informações acerca do comportamento dos envolvidos.

Sobre a vítima, conseguiram apurar, por intermédio do depoimento da esposa, que possuía vício de ingerir bebidas e chegava sempre alcoolizado. No dia do crime estava "em visível estado de embriaguez". No depoimento da menor, que tivera uma discussão anterior ao ocorrido, os agentes policiais conseguiram obter a informação de que o guarda civil teve uma conduta exemplar, pois de modo educado procurou aconselhar a vítima a não usar a faca. É ressaltado que o responsável pelo homicídio compareceu ao local "com o único fim de evitar uma contenda", apesar de "ter sido demasiadamente maltratado pela vítima". Aqui percebemos claramente como os depoimentos foram sendo construídos no sentido de destacar as qualidades do agente policial, para estabelecer um modelo de inocência que pudesse absolvê-lo das acusações.

No que tange ao episódio, os policiais obtiveram a informação de que a vítima portava uma faca, estava com os braços feridos e bradava as seguintes frases: "Eu mato qualquer um" e "Hoje eu fecho o paletó de um e estou chupando o meu sangue". Acrescentaram ainda que a vítima "parecia um anormal, em face da fúria em querer atender ao aludido policial que com gentileza o suportava". Nos depoimentos relacionados ao comportamento da vítima foram salientados justamente os aspectos negativos para que a ação policial fosse vista como legítima.

Em seu depoimento, o acusado acentuou ainda mais a imagem negativa da vítima em relação aos seus antecedentes e também no momento do episódio. Declarou, por exemplo, que quando estava voltando para casa, ao ser abordado pela vítima, ouviu a expressão: "Coroa, vou lhe fechar o paletó". Relatou que a vítima veio em sua direção com uma faca, e "não teve alternativa, senão sacar de sua arma". Disse também estar portando uma "por acaso", e que ao disparar contra seu agressor procurou atingi-lo nas pernas. Fez questão de registrar que pensou em procurar socorro, mas foi aconselhado por alguns meninos para abandonar o local, porque estava correndo risco, pois a vítima tinha "amigos marginais" que moravam na redondeza.

Diante desse cenário reconstruído pelos vários depoimentos, o advogado de defesa argumentou que seu cliente agiu em legítima defesa, 
porque usou moderadamente os meios necessários. Destacou ainda que o mesmo "não é um criminoso vulgar, que mate por prazer", já que agira daquela forma porque tinha o "dever de zelar" pela sociedade.

Um padrão de depoimento encontrado em vários processos foi de que o policial não havia atirado para acertar a vítima, que tinha sido um acidente. Nesse episódio, por exemplo, o guarda civil afirmou que ao disparar a arma, a "vítima caiu"; logo, se tratava de uma "fatalidade". Todos os indícios apontaram que o guarda civil não usava a arma por acaso e muito menos que o tiro foi disparado de forma acidental.

Todavia, o advogado construiu a tese de defesa postulando que seu cliente - o guarda civil - agira em legítima defesa porque seu agressor representava um perigo para a sociedade. Para tanto, salientou que a vítima tentara matar um vizinho e ameaçara outras pessoas de morte. Em relação ao comportamento da vítima na vida familiar e coletiva, elementos por demais realçados nas peças processuais, a tese de defesa argumentou que este era "violento", "turbulento" e que a vítima causava constante intranquilidade aos vizinhos, além de agredir fisicamente sua companheira. A intenção foi de caracterizar a vítima como uma pessoa "anormal", com uma personalidade "deturpada".

Fica claro que, desde o início do processo, foi sendo construída uma imagem da vítima para legitimar a ação empreendida pelo guarda civil. Vários aspectos relativos ao perfil psicológico e social da vítima foram enfatizados para que sua morte fosse vista não como uma perda, mas como um favor prestado pelo guarda civil à sociedade e aos vizinhos. Em nenhum momento foi questionado se o guarda civil agira dentro dos padrões da legalidade ou mesmo se a forma como resolveu o litígio era a mais adequada. A justiça criminal simplesmente legitimou a ação do agente público sem qualquer discussão mais aprofundada sobre a sua conduta no episódio.

Nesse processo, a justiça criminal aceitou a tese de defesa do guarda civil com base em constructos produzidos pelo campo jurídico de que pessoas pertencentes às classes populares possuíam todos os tipos de vícios e maus costumes. Aliás, esses postulados foram utilizados pelo advogado de defesa para construir o modelo de inocência de seu cliente.

Não obstante, além desse quesito faz-se mister destacar que o guarda civil se arvorou no direito de empregar o uso da violência para resolver 
uma situação de conflito. Esse agente público utilizou o seu próprio conceito de justiça para livrar o bairro de um cidadão tido como detentor de um comportamento moral deturpado; considerou que atirar deveria ser o padrão a ser utilizado, em uma demonstração de que as formas de violência se manifestam também onde ocorrem interações concretas entre policiais e pessoas da sociedade, sem necessariamente envolver a rotina de trabalho das forças repressivas.

O próximo auto criminal é relativo a uma denúncia feita pelo Ministério Público, de que em um local denominado Buraco da Lacraia um rapaz conhecido como Guará fora alvo de vários disparos de arma de fogo, que causaram sua morte. Já no início do inquérito o delegado delineia o perfil da vítima. No despacho, em que solicita a realização de diligências para apurar o crime, argumenta tratar-se de um "desordeiro", que fora "assassinado com um tiro na nuca" (Processo no 1.960, 1955).

De fato, a vítima era um rapaz de 18 anos de idade acusado de ter cometido vários atos considerados ilícitos pelo sistema legal. Com 16 anos, foi processado pela primeira vez por roubo; constam também informações sobre facilitação de uso de entorpecente, ameaça, homicídio e estupro. A ficha referente a sua vida pregressa registra que dos pais só havia informação sobre os nomes; além disso, que fora criado "sem freios paternos e assistência social".

Consta ainda que vivera um período de internamento no SAM - Serviço de Assistência a Menores - para que "cessasse sua periculosidade"; todavia, fugira do local. Não foi um caso isolado, porque constavam reclamações de que inúmeros menores estavam evadindo-se frequentemente do estabelecimento. Desde a infância, morou na favela Buraco da Lacraia, próxima ao Bairro São Cristóvão. O próprio local em que residia carregava um forte estigma, pois recebera a denominação de um bicho peçonhento, considerado perigoso.

Como se tratava de processo envolvendo policial, aos poucos as informações foram chegando até que fosse oferecida denúncia pela promotoria. Por exemplo, na ocorrência registrada no $16^{\circ}$ Distrito Policial, o investigador simplesmente comunicou que na favela Buraco da Lacraia havia o cadáver de um homem, sendo apurado posteriormente que se tratava de um "malandro e salteador" conhecido por Guará. Assinalou que, ao interrogar a irmã da vítima, ficara sabendo se tratar-se de uma 
pessoa "que levava uma vida fora da lei, tinha muitos inimigos e não trabalhava honestamente".

$\mathrm{O}$ primeiro investigador a recolher informações a respeito do episódio pontuou que não conseguira "descobrir" muita coisa, nem mesmo quem atirara na vítima, uma vez que as pessoas no local relataram não saber de nada. No que tange à vítima, reforçou a percepção de que se "tratava de um indivíduo de péssimos antecedentes com diversos crimes de morte, sendo componente de uma quadrilha de desordeiros das favelas Buraco da Lacraia, Barreira do Vasco, Beco da Manilha e Pau Rolo”.

Lendo os depoimentos, a impressão é de que as pessoas tinham receio de denunciar o autor do crime. $\mathrm{O}$ vigilante municipal, morador da região e autor do homicídio, aparece apenas como aquele que comunicou o fato à polícia, dizendo que ficara sabendo do crime por intermédio de um telefonema anônimo. Aliás, quando ligou para o Distrito Policial fez questão de ressaltar que, no lugar denominado Buraco da Lacraia, "se encontrava o malfeitor juntamente com seu bando, todos armados com arma de fogo, pondo em sobressalto os moradores daquele local, exibindoas ostensivamente". Em novas diligências, os policiais fizeram questão de relatar que "todos os circunstantes presentes moradores do local foram unânimes em declarar que se tratava de um elemento perigoso e que sua morte constituía um alívio geral para todos".

No início das investigações, os policiais procuraram atribuir o crime a outras pessoas que moravam no local, como se fosse um acerto de contas entre inimigos fora da lei. Não é sem sentido haver a menção reiterada de que a vítima convivia com pessoas "fora da lei", pertencentes a uma "quadrilha de desordeiros". No Boletim de Ocorrência, por exemplo, foi evidenciado um depoimento fornecido pela irmã, de que seu irmão "tinha muitos inimigos, embora não os conhecesse". Nos depoimentos, sempre aparece realçada a morte da vítima, seu "fim trágico", como se fosse o "natural epílogo" de alguém fora da lei.

Esses depoimentos prestados pelas testemunhas e pelos familiares, nos quais não há qualquer menção acerca da autoria do assassinato, vieram a calhar para a estratégia dos policiais de impedir que fosse descoberto o responsável pelo crime. A mãe, os vizinhos e os depoentes, aceitando a morte do rapaz "como um alívio", permitiam o encerramento do caso sem maiores esclarecimentos. 
A intenção era forjar a ideia de que não havia muito sentido ficar se preocupando em apurar as causas da morte de uma pessoa considerada um "bandido" pelos moradores do local. Importava, de fato, salientar que Guará representava uma "ameaça" porque vivia deixando em sobressaltos a vizinhança e não possuía nenhuma qualidade, já que sempre levara uma vida "desregrada".

No entanto, essa estratégia não surtiu efeito, pois o delegado enviou um documento ao corregedor manifestando seu constrangimento em prosseguir o trabalho. No documento da Corregedoria, fica evidente que os policiais estavam criando inúmeros obstáculos para impedir a revelação do nome do verdadeiro responsável pelo crime, principalmente porque o laudo cadavérico havia mostrado que o tiro tinha sido dado pelas costas. Aliás, um dos motivos alegados pelo juiz para levar o caso a julgamento era justamente porque "a vítima foi ferida certeira e mortalmente no crânio pelas costas".

Com a indicação de outro delegado para conduzir as investigações, o vigilante municipal passou a ser acusado de homicídio, sendo chamado a prestar depoimento. A partir desse momento o indiciado relatou o episódio, e em sua versão afirmou que agira em legítima defesa à medida que reagira a uma agressão, visto que a vítima havia atirado em sua direção. Um padrão que notamos nos processos com o envolvimento de policiais e que se repete nesse também: não admitir que disparara diretamente para a vítima, como se houvesse certo constrangimento em se assumir o assassinato de uma pessoa.

Ao longo do processo, o vigilante municipal forneceu diferentes versões acerca da forma como a vítima fora atingida. Primeiramente revelou que "atirou com a intenção de assustá-lo", lhe parecendo "que o tiro acertara de raspão". Não podendo sustentar esse depoimento, em juízo afirmou ter feito disparos contra a vítima, para o alto; como estivesse em uma posição abaixo, pois o terreno era inclinado, acertou acidentalmente. Embora não sejam somente esses elementos levados em consideração no interior do tribunal, o "tiro acidental" é uma estratégia utilizada para atenuar a gravidade do crime e até mesmo para conseguir uma absolvição, haja vista ser fundamental esclarecer a forma como o crime foi praticado. Para definir os aspectos agravantes e atenuantes é essencial determinar claramente se o crime foi doloso ou culposo. 
Para sustentar essa tese e dar credibilidade à versão do policial fezse necessário apontar outros aspectos diante do tribunal. De antemão, o policial relatou que fora chamado ao local a pedido de um morador, porque um "conhecido desordeiro", vulgo Guará, juntamente com outros dois comparsas, conhecidos por Kerozene e Nariz Cortado, vinha praticando assaltos. Acrescentou ainda o fato de ter conhecimento que a vítima "era um elemento perigoso, tendo mesmo várias vezes atirado em policiais, sendo procurado como desordeiro, assaltante e assassino".

Para sustentar os argumentos do policial acerca de sua ação, que redundara na morte da vítima, foi anexado ao processo um documento em que se procurava trazer informações sobre a vida pregressa e os antecedentes criminais dos envolvidos. Em relação ao policial, só havia aspectos positivos no tocante a sua conduta, uma estratégia muito utilizada de vitimizar o culpado e culpabilizar a vítima.

No tocante às informações referentes à vida pregressa da vítima, cabe aqui uma análise mais demorada. Consta um relato circunstanciado, no qual se procurou enumerar todos os detalhes de sua trajetória de vida enquanto morador de um local, o Buraco da Lacraia, "que sempre teve lugar de destaque nos anais do crime da capital", para que o ato cometido contra a vítima não fosse visto como contrário aos princípios da lei e do direito. Mais ainda, de que a morte de uma pessoa "rebelde desde pequeno", que "jamais trabalhou" ou "frequentou escola" fosse vista como legítima. Esse documento da polícia vai ao encontro do pensamento jurídico-penal do período, de que nesses bairros as pessoas viviam em "uma promiscuidade de arrepiar" e possuíam um "sprit de corps para o crime".

A mudança no comando das investigações não alterou significativamente os rumos do processo no sentido de responsabilizar criminalmente o vigilante municipal ou mesmo de se formalizar uma denúncia de acusação mais fundamentada de que a vítima tinha sido executada. Aliás, o juiz, quando fez o despacho para levar o policial a júri, realçou que "o mau passado da vítima não autorizava sua eliminação”. De fato, deparamo-nos com vários procedimentos judiciais visando a desqualificar juridicamente a vítima, tentando convencer ou mesmo obter certa aquiescência de que a ação que redundou na morte do rapaz era "necessária" e, no limite, "indispensável". 
Portanto, não é sem sentido ter enfatizado que, desde a infância, a vítima, que perdeu a identidade ao ser nomeada somente de Guará, já tinha como companheiros os "mais renomados elementos da rapinagem". Para caracterizar sua "tendência natural" de viver "sempre a margem da sociedade", consta que "aos treze anos teve como professor na arte de assaltar o famoso Silico, de quem fora discípulo dileto e de quem herdara a audácia e o sangue frio". Apesar de ter somente inimigos no ambiente em que vivia, "ainda assim o temível salteador conseguiu imperar com outros azes por muitos anos, apesar de contar apenas dezoito anos de idade quando morreu".

Além de informações sobre a vida da vítima strictu sensu, havia também partes mencionando a opinião de outras pessoas no que se refere à conduta e ao comportamento do autor do crime, bem como o sentimento destas em relação ao episódio que vitimou o rapaz. Anexou-se ao processo um abaixo-assinado dos moradores do local solicitando a liberdade do policial quando da decretação de sua prisão preventiva.

A construção de todo o procedimento judicial, mesmo sendo comprovada a execução sumária, é no sentido de reforçar que a ação policial fora legítima, pois se tratava de uma pessoa que vivia "fora dos limites". Ademais, como dizia respeito à morte de alguém com antecedentes criminais e sociais deveras desabonadores, o comportamento do policial não deveria ser visto como uma violação de regras consensuais de justiça e dos regulamentos das forças policiais da capital federal. Não só isso, mas que a ação fora legítima porque os policiais agiram no sentido de livrar a sociedade de um "mau elemento".

Outro processo analisado versa sobre uma ação de rotina dos policiais. A denúncia do Ministério Público relata que, por volta das três horas da madrugada, no centro da cidade, dois guardas civis efetuaram disparos que provocaram a morte de um homem pardo, original do Espírito Santo, com 26 anos de idade, pintor, residente no Morro de São Carlos. Consta nos autos que o ferimento do projétil estava localizado nas costas, abaixo da omoplata (Processo no 845, 1950).

Em um dos primeiros documentos elaborados no interior da Delegacia, a versão era de que os policiais realizavam um trabalho para "manter a ordem" e tiveram de fazer vários disparos contra "malfeitores e desordeiros". Na sequência, o relato é de que os guardas civis foram 
desrespeitados ao tentarem "impor ordem a um grupo de turbulentos que promoviam desordens no Café Casa Real”. A vítima, por exemplo, "passou uma rasteira no guarda civil, ocasião em que ambos os policiais fizeram uso de suas armas, efetuando os disparos".

No depoimento de uma testemunha é possível avançarmos na compreensão do episódio. Em sua versão, no início da madrugada chegaram vários "indivíduos desconhecidos" que, após tomarem algumas cervejas, começaram a falar alto. O guarda municipal que fazia a ronda pediu para eles deixarem o estabelecimento, passando a segui-los pelas ruas. Passado algum tempo, voltou ao estabelecimento para comunicar à Rádio Patrulha e ao serviço de ambulância de que havia um homem ferido na rua.

Sobre o ocorrido em seguida, temos o relato de um juiz morador da vizinhança de que ouvira vozes vindas da rua. Contou que o guarda civil pedira aos rapazes para irem embora, mas um deles respondeu que teria que prestar conta a um primo policial. O guarda civil se irritou e foi em direção aos rapazes e sacou de uma arma, fazendo vários disparos. $\mathrm{Na}$ sequência, um outro guarda civil que estava do outro lado da rua também efetuou alguns disparos na direção dos rapazes.

Cabe salientar que essa versão do juiz não foi confirmada pelos policiais. Nos depoimentos, afirmaram terem atirado para cima para intimidar, pois, conforme o guarda municipal, uma das vítimas estava com uma navalha na mão. Novamente se repete um padrão de depoimento quando os policiais estavam sendo processados por crimes de homicídio, de não admitirem que atirassem diretamente na vítima.

Orientados pelos advogados, construíram a tese de defesa de que o tiro fora acidental. Para o advogado de defesa, por exemplo, os acusados "fizeram disparos para o ar". Os réus procuraram mostrar que se encontravam em uma situação em que precisavam agir daquela forma, já que estavam diante de pessoas que os colocavam em perigo. Evidenciaram o mau comportamento da vítima, tratando de enfatizar sua conduta desabonadora. Com esses argumentos, conseguiram a absolvição.

O último auto criminal trata de um episódio em que vários policiais invadiram uma casa por volta de meia noite, localizada em Realengo, quando várias pessoas jogavam baralho. Nesse episódio, foram 
denunciados quatro policiais, um delegado, um comissário de polícia, um escrivão e um comerciante. Devemos registrar que só encontramos o primeiro volume do processo, contendo quatrocentas páginas (Processo $\left.\mathrm{n}^{\mathrm{o}} 558,1947\right)$. Contudo, para os propósitos deste artigo, essas peças processuais foram de grande utilidade. Foi-nos possível acompanhar o trâmite de um procedimento judicial em que uma pessoa de sessenta anos foi assassinada e outras ficaram feridas devido a uma blitz policial no interior de uma residência para acabar com um jogo.

Convém destacarmos que o episódio ocorreu em 1947, mas o Ministério Público só conseguiu oferecer a denúncia em 1952, portanto, cinco anos depois. Nesse documento, foi relatado que passava um pouco da meia-noite quando uma das pessoas do interior da casa pressentiu alguém se aproximando. Vieram saber depois que se tratava de cinco policiais, intencionados em acabar com o jogo de "sueca" praticado na casa da vítima, que veio a falecer.

Como os parceiros do jogo perceberam que eram policiais, apagaram a luz; mesmo assim, os agentes adentraram o local, passando a iluminar a mesa de jogo com uma lanterna. Logo em seguida, um dos denunciados disparou a arma, vindo a atingir o proprietário da casa, que se achava sentado em frente aos policiais. O promotor público, com base nos depoimentos prestados pelas testemunhas e vítimas, relatou o fato de as pessoas não ofereceram resistência; aliás, todos "ficaram surpreendidos com a violência arbitrária, desnecessária e brutal dos denunciados".

No relatório, consta que as pessoas ficaram amedrontadas, e quando uma das vítimas tentou sair do local também foi atingida por tiros disparados pelo mesmo policial. Um capitão do Exército, morador da casa ao lado, ao ouvir os tiros se aproximou do local e interpelou os policiais. Ouviu como resposta que estava sendo providenciado socorro, porém os agentes simplesmente desapareceram.

A partir dessas constatações, a Promotoria Pública ofereceu denúncia contra vários agentes policiais; uns porque estavam envolvidos diretamente com a morte de uma das vítimas e a lesão da outra, outros porque não realizaram nenhuma investigação para descobrir a autoria do delito, e esconderam provas. Por último, o delegado foi acusado de não tomar providências, de coação de testemunhas e de falsa divulgação dos fatos na imprensa para proteger seus subordinados. A propósito, o 
delegado deu uma informação completamente deturpada para um dos periódicos e impediu outros jornais de saberem das investigações. Logo, o "furo" de notícia dado por esse periódico, que consta inclusive nas peças processuais, não passou de um engodo do delegado.

Voltando à análise do processo, convém apontar que, diante das inúmeras ilegalidades, foi designado outro delegado para conduzir as investigações. A denúncia feita pela Promotoria Pública, decorridos cinco anos dos acontecimentos, teve por base a apuração ocorrida depois da substituição das pessoas responsáveis pela apuração do crime.

Novamente nos deparamos com um processo em que vários policiais estavam envolvidos e a dinâmica empreendida foi a de, primeiramente, utilizar todos os mecanismos para evitar a denúncia contra os acusados do crime. Nesse processo, foi possível ainda percebermos como os agentes policiais, em uma rede que ia daquele que estava na rua, passando pelo comissário e o escrivão, até chegar ao delegado; agiram no sentido de falsificar as provas e ameaçar as testemunhas para que os invasores de domicílio e assassinos não fossem denunciados pelo crime.

Embora estejamos registrando que os policiais invadiram a residência da vítima, não nos foi possível constatar se estava localizada em uma favela; porém, pelas fotos dos autos, notamos que se tratava de um bairro de classe popular, desprovido de qualquer tipo de infraestrutura urbana. Salientamos essa questão porque as residências localizadas em favelas não são consideradas legalizadas pelos poderes públicos. Dessa forma, as invasões de domicílio realizadas nesses locais por policiais não são consideradas crime, o que evidencia como os direitos civis e individuais são violados simplesmente porque se vive em uma região periférica da cidade.

Em relação a esse episódio de invasão de policiais em uma residência para acabar com o jogo de "sueca", devemos acrescentar que o governo tinha uma política mais ampla de acabar com várias modalidades de jogos na sociedade brasileira. O código penal de 1940 já previa punição para as pessoas praticantes de jogos de azar;; contudo havia um trabalho

3 Lei das Contravenções Penais - Decreto Lei no 3.688 - 03/10/1941 - Art. 50 Estabelecer ou explorar jogo de azar em lugar público ou acessível ao público, mediante o pagamento de entrada ou sem ele. Pena - prisão simples, de três meses a um ano, e multa, de dois a quinze contos de réis - estendendo-se os efeitos da condenação à perda dos móveis e objetos de decoração local. 
mais sistematizado por parte do aparato repressivo no sentido de coibir os jogos, principalmente aqueles envolvendo as classes populares.

Notamos claramente que, em mais um episódio envolvendo policiais, o Poder Judiciário acabou sendo leniente com as ações ilegais de policiais que cometeram arbitrariedades no exercício da função. Em mais um episódio a instituição responsável pelo cumprimento das leis foi conivente com as arbitrariedades cometidas pelos agentes públicos.

\section{Conclusão}

Podemos considerar que a sociedade brasileira passou a vivenciar um dos momentos mais significativos de sua história. Acreditava-se que estávamos caminhando rumo a um mundo efetivamente moderno. O país passou por significativas transformações sociais, econômicas e culturais e também vivenciou um intenso processo de urbanização, com a formação de inúmeras cidades e regiões metropolitanas.

Diante dessa nova configuração da sociedade brasileira, o pensamento social brasileiro construiu um discurso de que as classes populares não possuíam um nível cultural que lhes permitissem viver plenamente nos padrões sociais da modernidade. A concepção reinante supunha que as classes populares estavam fadadas a viver na marginalidade, uma vez que não detinham instrumental necessário para participar da civilização urbano-industrial.

Para o pensamento jurídico-penal, essa situação de déficit cultural, na qual se encontravam as classes populares, resultava em comportamentos e condutas antissociais e antijurídicas. Aliás, um dos mais destacados criminalistas do período afirmava enfaticamente que esses segmentos sociais viviam em perenes focos criminógenos e áreas de delinquência endêmicas. Por conseguinte, havia a pregnância no pensamento jurídicopenal de culpabilizar fortemente as classes populares pelas suas condutas e comportamentos.

Quanto à justiça criminal, fica evidente que a intervenção para coibir a ilegalidade e o arbítrio das forças policiais estava impregnada desses princípios e postulados. Tanto que, em vários episódios nos quais os agentes públicos foram prestar contas de suas ações perante o sistema 
judiciário, sempre justificavam que a força e a violência haviam sido utilizadas contra pessoas desordeiras e marginais.

$\mathrm{Na}$ realidade, os policiais encontraram um respaldo muito grande por parte do sistema judiciário quando postulavam que estavam utilizando a violência contra pessoas com péssimos antecedentes ou que viviam em áreas tidas como focos de criminalidade. A impressão é de que nesse momento em que mais se buscou introduzir os padrões da modernidade na sociedade brasileira o arbítrio e a violência do Estado não foram coibidos pelo Poder Judiciário.

Em suma, em uma conjuntura em que mais foi discutido o avanço da modernidade no país, o Poder Judiciário não atuou no sentido de fazer com que o Estado exercesse o monopólio da violência dentro dos padrões da legalidade. Portanto, um dos aspectos mais importantes da vivência de um Estado de direito, que é a garantia dos direitos individuais e civis, foi sistematicamente violado, porque o Poder Judiciário legitimou em grande medida as ações arbitrárias realizadas por policiais.

\section{Fontes}

\section{Autos criminais}

Processo nº 558/1947 - $1^{\text {a }}$ Vara Criminal - Tribunal do Júri - Rio de Janeiro.

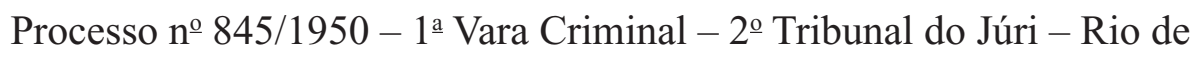
Janeiro.

Processo no 1960/1955 - 1aㅡ Vara Criminal - 2o Tribunal do Júri - Rio de Janeiro.

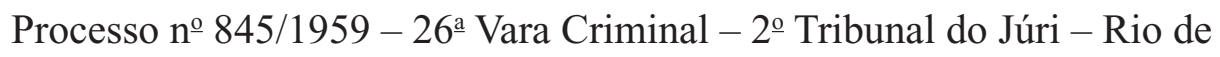
Janeiro.

\section{Legislação}

Lei das Contravenções Penais - Decreto Lei no 3.688 de 3 de outubro de 1942.

Código Penal - Decreto Lei oㅡ 2.848 de 7 de dezembro de 1940.

Código de Processo Penal - Decreto Lei no 3.688 de 3 de outubro de 1942. 
Revistas

HUNGRIA, Nelson. A criminalidade dos homens de cor. Revista Forense, Rio de Janeiro, v. 134, mar. 1951.

HUNGRIA, Nelson. Discurso na sessão inaugural da 1ํㅡㄹ Conferência PanAmericana de Criminologia. Revista Forense, Rio de Janeiro, v. 114, nov. 1947.

LACERDA, Romão Cortes. O alarmante incremento da criminalidade violenta no Brasil. Revista Forense, Rio de Janeiro, v. 186, nov./dez. 1959.

MEUREN, Waldir. Breves considerações sobre a lei das favelas. Revista Forense, Rio de Janeiro, v. 186, nov./dez. 1959.

VEIGA, A. César. A temibilidade criminal na atualidade jurídica brasileira. Revista Forense, Rio de Janeiro, v. 140, mar./abr. 1952.

\section{Referências}

ABREU, Alzira Alves de (Org.). A imprensa em transição: o jornalismo brasileiro nos anos 50. Rio de Janeiro: Ed. Fundação Getúlio Vargas, 1996.

ADORNO, Sérgio. Crime, justiça penal e desigualdade jurídica - as mortes que se contam no Tribunal do Júri. Revista USP, n. 21, São Paulo, mar./abr./maio 1994.

ADORNO, Sérgio. Discriminação racial e justiça criminal em São Paulo. Novos Estudos Cebrap, n. 43, São Paulo, nov. 1995.

ADORNO, Sérgio. Os aprendizes do poder. Rio de Janeiro: Paz e Terra, 1988.

BONDUKI, Nabil. Crise de habitação e luta pela moradia no pós-guerra. In: KOWARICK, Lúcio (Org.). As lutas sociais e a cidade. Rio de Janeiro: Paz e Terra, 1988.

BOURDIEU, Pierre. O poder simbólico. Lisboa: Difel, 1989.

BRETONE, Mario. Derecho y tiempo em la tradición européa. México: Fondo de Cultura Econômica, 2000. 
CALDEIRA, Teresa Pires do Rio. Direitos humanos ou "privilégios de bandidos"? Novos Estudos Cebrap, São Paulo, n. 30, jul. 1991.

CHARTIER, Roger. Textos, impressões e leituras. In: HUNT, Lynn. $A$ nova história cultural. São Paulo: Martins Fontes, 1992.

FARIA, Vilmar. Desenvolvimento, urbanização e mudanças na estrutura do emprego: a experiência brasileira nos últimos trintas anos. In: SORJ, Bernard; ALMEIDA, Maria Hermínia Tavares de (Org.). Sociedade e política no Brasil pós-64. São Paulo: Brasiliense, 1983.

GINZBURG, Carlo. Mitos, emblemas e sinais: morfologia e história. São Paulo: Cia das Letras, 1989.

GOMES, Ângela de Castro. A política brasileira em busca da modernidade: na fronteira entre o público e o privado. SCHWARCZ, Lilia Moritz (Org.). História da vida privada no Brasil: contrastes da intimidade. v. 4. São Paulo: Cia das Letras, 2006.

KOWAQRICK, Lúcio. O capitalismo e a marginalidade na América Latina. Rio de Janeiro: Paz e Terra, 1975.

LOBO, Eulália Lahmeyer (Coord.) Rio de Janeiro Operário. Rio de Janeiro: Acess, 1992.

MAUAD, Ana Maria S. Andrade; GRINBERG, Lúcia. O século faz cinqüenta anos: fotografia e cultura política. Revista Brasileira de História, v. 14, n. 27, São Paulo, 1994.

MELLO, João Manuel C.; NOVAIS, Fernando A. Capitalismo tardio e sociabilidade moderna. In: SCHWARCZ, Lilia Moritz (Org.). História da vida privada no Brasil: contrastes da intimidade. v. 4. São Paulo: Cia das Letras, 2006.

NEDER, Gizlene. Discurso jurídico e ordem burguesa no Brasil. Porto Alegre: Sérgio Antonio Fabris, 1995.

NEVES, Lucília de Almeida. Trabalhismo, nacionalismo e desenvolvimentismo. In: FERREIRA, Jorge (Org.). O populismo e sua história: debate e crítica. Rio de Janeiro: Civilização Brasileira, 2001.

PANDOLFI, Dulce Chaves et al. (Org.). Cidadania, justiça e violência. Rio de Janeiro: Editora FGV, 1999. 
PINHEIRO, Paulo Sérgio. Autoritarismo e transição. Revista USP, São Paulo, n. 9, mar./abr./maio 1991.

ROLIM, Rivail Carvalho. O policiamento e a ordem: histórias da polícia em Londrina, 1948-1962. Londrina: Eduel, 2005.

ROLIM, Rivail Carvalho. Pensamento jurídico-penal sobre a criminalidade negra no Brasil, 1940-1960. The Latin Americanist, Charlote-USA, v. 51, n. 1, 2007.

RUSCHE, Georg; KIRCHHEIMER, Otto. Punição e estrutura social. Tradução de Gizlene Neder. Rio de Janeiro: Revan, 2004.

SCHWARCZ, Lilia Moritz (Org.). História da vida privada no Brasil: contrastes da intimidade. v. 4. São Paulo: Cia das Letras, 2006.

VENTURA, Zuenir. Cidade partida. São Paulo: Cia das Letras, 1994. ZALUAR, Alba. A máquina e a revolta: as organizações populares e o significado da pobreza. São Paulo: Brasiliense, 1985.

ZALUAR, Alba. Para não dizer que não falei de samba: os enigmas da violência no Brasil. In: SCHWARCZ, Lilia Moritz (Org.). História da vida privada no Brasil: contrastes da intimidade. v. 4. São Paulo: Cia das Letras, 2006. 